\title{
Vegetation Dynamics in Treeline Ecotone of Langtang National Park, Central Nepal
}

\author{
N.P. Gaire', Y.R. Dhakal' ${ }^{2}$, H.C. Lekhak ${ }^{2}$, D.R. Bhuju' ${ }^{1}$ and S.K. Shah ${ }^{3}$ \\ ${ }^{1}$ Nepal Academy of Science and Technology, Khumaltar, Lalitpur \\ ${ }^{2}$ Central Department of Environment Science, Tribhuvan University, Kirtipur, Kathmandu \\ ${ }^{3}$ Birbal Sahni Institute of Paleobotany, Lucknow, India \\ e-mail:npgaire2007@gmail.com
}

\begin{abstract}
A study was carried out at the treeline ecotone (3,730m-3,950m asl) of Langtang National Park in central Nepal with an aim to document the impact of climatic warming on ecological chracteristics. Three sampling sites were selected at Chaurikharka and Lauribina, where no serious anthropogenic pressure was noticed. The nearest meteorological station has records of climatic warming in recent years. Six tree species and three shrub species belonging to seven families were enumerated from the study plots. The average basal area for tree species was found to be $20.56 \mathrm{~m}^{2}$ per ha while average tree density was found to be 734 trees per ha with Abies spectabilis as dominant species. The mean DBH (diameter at breast height) of tree species was found to be $15.8 \mathrm{~cm}$ (max. $115.5 \mathrm{~cm}$ ). Density of dead trees accounted 2 no. per ha with basal area $0.195 \mathrm{~m}^{2}$ per ha. Average sapling and seedling density of tree species per ha was observed to be 1,590 and 831 respectively. The average sapling and seedling density of $A$. spectabilis was 255 and 350 per ha respectively. Similarly, average shrub density (per ha) for the area was found to be 9,609 no/ha. The stand character showed that there was high level of recruitment of $A$. spectabilis in the recent years. The presence of sapling and seedling of $A$. spectabilis at higher altitude showing linear relationship with canopy coverage indicated prospects for a gradual and upward shift of $A$. spectabilis with increased temperature.
\end{abstract}

Key words: Abies spectabilis, regeneration, climate change, DBH

\section{Introduction}

Tree line, a life form boundary that limits regional tree growth irrespective of the species (Becker et al. 2007) and a sensitive biomonitor of past and recent climate change and variability (Kullman 1998), is ideally suited for climate change monitoring (Becker et al. 2007). Past studies on tree line have shown that population structures at tree line ecotones are good indicators of climate change, where trees often respond to climatic warming with increase in recruitment or tree-density, as well as upward advances in the tree line (Kullman 2002, Camarero \& Gutiérrez 2004). As the location of northern hemisphere altitudinal and polar tree lines are much effected by heat deficiency, global warming is expected to cause tree lines to advance to higher elevations and more northerly latitudes (Grace et al. 2002).
Short term response of a year or less to climate change is reflected in individual trees, while medium-term response of some years to a few decades is mirrored in changing tree physiognomy (phenotypical response), tree-ring width and density, survival rate in seedlings and young trees, succession stage of the plant cover, etc. (Holtmeier \& Broll 2005). Moreover, the age structure of a stand can provide a fairly accurate picture of temporal variations in the establishment rate i.e. a static age structure of living trees is the expression of change in the rate of tree recruitment and mortality over time (Harcombe 1987 cited in Wang et al. 2006)). However, literature on the impact of climate change on forest vegetation and their distribution in Nepal is scarce. An ecological study, thus, was proposed and carried out at the tree line ecotone of the Langtang 
National Park (LNP) in central Nepal. The objective was to prepare baseline information on the tree line vegetation, their distribution pattern and regeneration of tree species for comparative studies.

\section{Materials and Methods \\ Climate of study area}

The meteorological station nearest to the study area of the LNP, was Kyanjing (3,920m asl) in Rasuwa district. Available data showed that average monthly total rainfall was maximum in August (172.76 mm) followed by July (171.14 mm) and the minimum was in December $(2.57 \mathrm{~mm})$. There was $0.163^{\circ} \mathrm{C}$ per year increment in the winter minimum temperature and the increment was statistically significant $(\mathrm{r}=0.51, \mathrm{p}=0.02)$. Analysis of 20 years data from 1988 to 2007 showed mean monthly temperature of the hottest (July) and coldest (December) month was $9.5^{\circ} \mathrm{C}$ and $-0.1^{\circ} \mathrm{C}$, respectively.

\section{Field survey and data collection}

The field study was carried out during August and September in 2007 in three sites of tree line ecotone: (I) Chaurikharka, (II) between Chaurikharka and Lauribina, and (III) Lauribina of the LNP. The details of the plot locations are shown in Fig.1. The study sites were located on north and north-west aspect of the mountain, and the altitude ranged from $3,730 \mathrm{~m}$ to 3,950m asl. The site had dense Abies forest with Rhododendron under-storey and above the tree line was rhododendron scrub.

Individuals of tree species were enumerated into three height classes: trees (>2 m), saplings (0.5-2 m) and seedlings ( $<0.5 \mathrm{~m}$ ) following Wang et al. (2006) and Kullman (2007). Sampling was carried out in four rows: one at Abies tree line, one above the tree line, and two below the tree line, with each row at 50 -m elevation intervals. Four plots $(20 \mathrm{~m} \times 20 \mathrm{~m})$ were established at each rows with first plot selected randomly from either side of the row of Abies limit. Second plot was selected systematically at $50 \mathrm{~m}$ walking distance from the first plot and so on. Accordingly, four plots were also established next row at 30-50m contour difference from preceding and following rows. A total of 48 plots $(20 \mathrm{~m} \times 20 \mathrm{~m})$, with 16 plots in the each site were established. The $20 \mathrm{~m} \times 20 \mathrm{~m}$ plot nested with two subplots of $5 \mathrm{~m} \times 5 \mathrm{~m}$ and $1 \mathrm{~m} \times 1 \mathrm{~m}$ in two opposite corners was laid to study shrubs and sapling, and seedling, respectively.

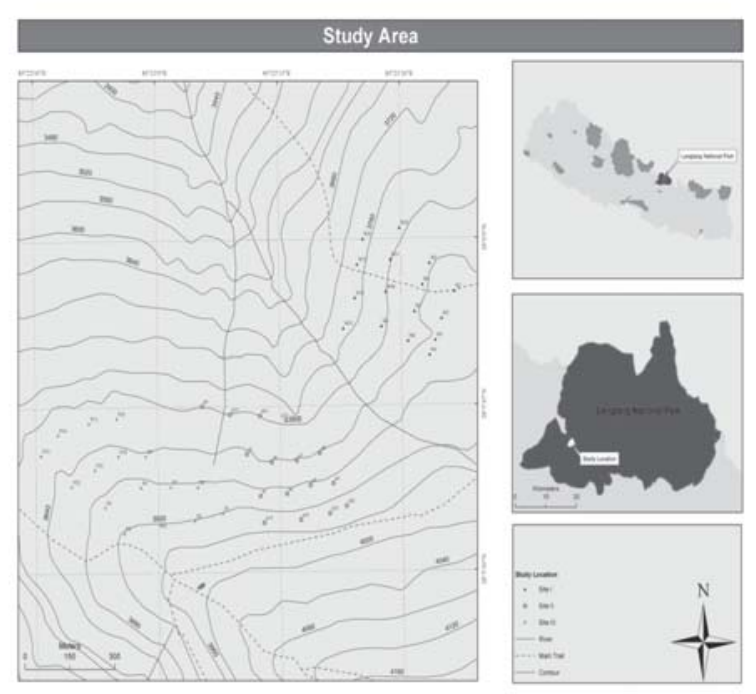

Fig. 1. Map showing study area and study sites

\section{Data analysis}

Data were analyzed using computer program MS Excel. The quantitative parameters viz., relative density, relative frequency, and relative basal area were calculated using standard formula (Ohsawa 1984).

\section{Results and Discussion}

\section{Floral Composition and Stand Characteristics of Tree Species}

Altogether 30 plants species were collected from the field survey at the three study sites: (I) Chaurikharka, (II) between Chaurikharka and Lauribina, and (III) Lauribina (Table1\&3). They belonged to 23 families, 13 families were represented by one species each; the highest number of species (four) belonged to family Ericaceae followed by three species to family Compositeae. By habit, out of 30 species, six were tree, three shrubs, and 21 herbs. Six tree species recorded were Abies spectabilis, Betula utilis, Juniperus recurva, Rhododendron campanulatum, Salix sp. and Sorbus microphylla at site I i.e Churikharka. Sites II and III contained four tree species recorded in site I except Juniperus recurva and Salix sp.

In a study, Shrestha et al. (2007) recorded two tree species from treeline ecotone in Manang, transHimalaya of central Nepal, which is less than our 
observation from Himalayan treeline. Present studied tree species richness (six species) is equitable to the tree species richness (five species from Pangboche and Debuche) at tree line in Sagarmatha area of Eastern Himalaya of Nepal reported by Bhuju et al. (2010). The present study has recorded most of these species, except Acer campbelli and R. campylocarpum. Kharkwal et al. (2005) reported four tree species and 41 shrubs between $3600 \mathrm{~m}$ and $3800 \mathrm{~m}$ altitude in Central Himalaya (Kumaun area) of the India.

Table 1 presents various structural parameters of tree species in three sites. The basal area was found to be 20.18, 17.78 and $23.72 \mathrm{~m}^{2}$ per ha in site I, II and III, respectively, with an average basal area $20.56 \mathrm{~m}^{2}$ per ha. The total tree density ranged from 550 trees per hectare in site III to 954 trees per hectare in site II while average tree density for the area was found to be 734 trees per hectare. Abies spectabilis was most frequent tree species in sites II and III with an average frequency of $87.5 \%$ and $91.7 \%$ while $R$. campanulatum was most frequent tree species in site I (Freq. 62.5\%). The Salix tree was least frequent species (Freq. 6.25\%) and was only found in site I. The mean DBH of tree was $15.8 \mathrm{~cm}$. Recorded highest DBH was $115.5 \mathrm{~cm}$ for A. spectabilis. Similarly highest DBH of $B$. utilis and $J$. recurva was $50.0 \mathrm{~cm}$ and $90.4 \mathrm{~cm}$, respectively. Some dead or damaged trees were also recorded which accounted 2 trees per ha with basal area $0.22 \mathrm{~m}^{2}$ per ha in Chaurikharka and 2 trees per ha with basal area $0.7 \mathrm{~m}^{2} /$ ha in Lauribina. In terms of Importance Value Index (IVI), A. spectabilis was the most important tree in site II and III and second most important species in site I.

Table 1. Structural parameters of tree species in three sites

\begin{tabular}{|c|c|c|c|c|c|c|c|c|c|c|}
\hline \multicolumn{2}{|r|}{ Species } & \multicolumn{2}{|c|}{ Basal Area } & \multicolumn{2}{|c|}{$\begin{array}{c}\text { Stem } \\
\text { Density }\end{array}$} & \multicolumn{2}{|c|}{ Frequency } & \multicolumn{2}{|c|}{ DBH } & \multirow[t]{2}{*}{ IVI } \\
\hline \multicolumn{2}{|c|}{ Chaurikharka } & $\mathbf{m}^{2} / \mathbf{h a}$ & RBA (\%) & per ha & RD (\%) & $\mathbf{F}(\%)$ & RF (\%) & $\begin{array}{c}\text { Mean } \\
(\mathrm{cm})\end{array}$ & $\begin{array}{l}\text { Max } \\
\text { (cm) }\end{array}$ & \\
\hline 1 & Abies spectabilis & 9.83 & 48.72 & 172 & 24.76 & 62.5 & 26.3 & 18.4 & 115.5 & 99.7 \\
\hline 2 & Rhododenderon campanulatum & 7.00 & 34.67 & 481 & 69.06 & 87.5 & 36.8 & 9.7 & 21.8 & 141 \\
\hline 3 & Juniperus recurva & 2.84 & 14.05 & 34 & 4.93 & 43.75 & 18.4 & 14.2 & 90.4 & 37.4 \\
\hline 4 & Sorbus microphylla & 0.12 & 1.9 & 5 & 0.67 & 18.75 & 7.89 & 15.8 & 24.5 & 10.5 \\
\hline 5 & Betula utilis & 0.38 & 0.61 & 3 & 0.45 & 18.75 & 7.89 & 37.5 & 50 & 8.95 \\
\hline \multirow[t]{2}{*}{6} & Salix sp. & 0.01 & 0.04 & 2 & 0.22 & 6.25 & 2.63 & 8.5 & 8.5 & 2.89 \\
\hline & Total & 20.18 & 100 & 697 & 100 & 237.5 & 100 & 17.3 & 115.5 & 300 \\
\hline \multirow[t]{2}{*}{1} & dead Betula utilis & 0.22 & 100 & 2 & 100 & 6.25 & 100 & 10.5 & 10.5 & - \\
\hline & dead Total & 0.22 & 100 & 2 & 100 & 6.25 & 100 & 10.5 & 10.5 & - \\
\hline \multicolumn{11}{|c|}{ Between Chaurikharka and Lauribina } \\
\hline 1 & A. spectabilis & 9.40 & 52.8 & 354 & 37.1 & 87.5 & 29.8 & 17.2 & 72 & 95 \\
\hline 2 & R. campanulatum & 5.32 & 29.9 & 423 & 44.3 & 87.5 & 29.8 & 11.2 & 29 & 74.5 \\
\hline 3 & B. utilis & 2.38 & 13.4 & 131 & 13.7 & 62.5 & 21.3 & 20.3 & 40.8 & 39.3 \\
\hline \multirow[t]{2}{*}{4} & S. microphylla & 0.68 & 3.8 & 46 & 4.8 & 56.3 & 19.2 & 9.5 & 14.5 & 24.6 \\
\hline & Total & 17.78 & 100 & 954 & 100 & 293.8 & 100 & 14.6 & - & 300 \\
\hline \multicolumn{11}{|c|}{ Lauribina } \\
\hline 1 & Abies spectabilis & 19.17 & 80.8 & 257 & 46.7 & 91.7 & 34.2 & 26.25 & 94 & 161.8 \\
\hline 2 & Rhododenderon campanulatum & 2.39 & 10.1 & 233 & 42.4 & 66.66 & 25 & 8.17 & 20.2 & 77.4 \\
\hline 3 & Betula utilis & 1.40 & 5.9 & 35 & 6.4 & 50.0 & 18.7 & 18.14 & 40.5 & 31.0 \\
\hline \multirow[t]{2}{*}{4} & Sorbus microphylla & 0.76 & 3.2 & 25 & 4.5 & 58.33 & 21.9 & 10.93 & 35 & 29.6 \\
\hline & Total & 23.72 & 100 & 550 & 100 & 266.69 & 100 & 15.63 & 94 & 300 \\
\hline \multirow[t]{2}{*}{1} & dead Abies spectabilis & 0.17 & 100 & 2.1 & 100 & 6.25 & 100 & 32 & 32 & - \\
\hline & dead Total & 0.17 & 100 & 2.1 & 100 & 6.25 & 100 & 32 & 32 & - \\
\hline
\end{tabular}

Note: RBA= Relative Basal Area, RD= Relative Density, F=Frequency, RF= Relative Frequency, DBH= Diameter at Breast Height, IVI= Importance Value Index 
Tree density (734 stem per hectare) in present study was higher than tree density observed by Bhuju et al. (2010) from treeline of Sagarmatha National Park. Bhuju et al. (2010) recorded total basal area of $11.2 \mathrm{~m}^{2}$ $\mathrm{ha}^{-1}$ and a density of 445 stems ha $^{-1}$, from treeline and basal area of $18.6 \mathrm{~m}^{2} \mathrm{ha}^{-1}$ and a density of 1,034 stems $\mathrm{ha}^{-1}$ from timberline region. In the present study, the higher tree density than that of eastern Himalaya may also be because of its lower elevation. The DBH $(115.5 \mathrm{~cm})$ of $A$. spectabilis in present study was higher than that observed from other treeline regions of Nepal (e.g. Shrestha et al. 2007, Bhuju et al. 2010) which indicates continuous establishment of tree from long time back in this area. The basal area ratio at treeline ecotone in present study is less than the basal area ratio reported by Shrestha et al. (2007). From a study in trans- Himalayan treeline, Shrestha et al. (2007) reported $B$. utilis as dominant tree species in the north facing treeline. In a study from Annapurna range, Ghimire and Lekhak (2007) reported B. utilis as dominant tree above $3,800 \mathrm{~m}$ belt and Pinus wallichiana and $A$. spectabilis as dominant trees in 3,500-3,800m belt. This study observed decrease of tree density with increase in altitude which is similar to the observation of Shrestha et al. (2007) in the trans-
Himalayan treeline and Bhuju et al. (2010) in Eastern Himalayan treeline. In a study from Pisang of Annapurna conservation area, Acharya et al. (2007) reported the highest IVI of $P$. wallichiana followed by $A$. spectabilis.

\section{Diameter Class Distribution of Trees}

Fig.2. presents diameter class distribution of major tree species. The diameter class distribution of $A$. spectabilis was found an inverse $\mathrm{J}$ shaped in sites I and site II while bell shaped distribution in site III. Bimodal and bell shaped distribution of B. utilis was observed in both sites II and III while only few individuals were present in the site I. Inverse J shaped diameter class distribution was observed for $R$. campanulatum in all three sites. However, the trend is not continuous but shows gaps between the classes in individual species. Gaps in the diameter classdistribution indicate logging in the recent past or episodic recruitment of tree species. Site III (Lauribina) is situated near to the human settlement; gaps in distribution might be due to anthropogenic disturbances. Since, we took height as a criterion to separate tree individuals, observed low number of individuals in $0-5 \mathrm{~cm}$ DBH class of most tree species may be due to that.
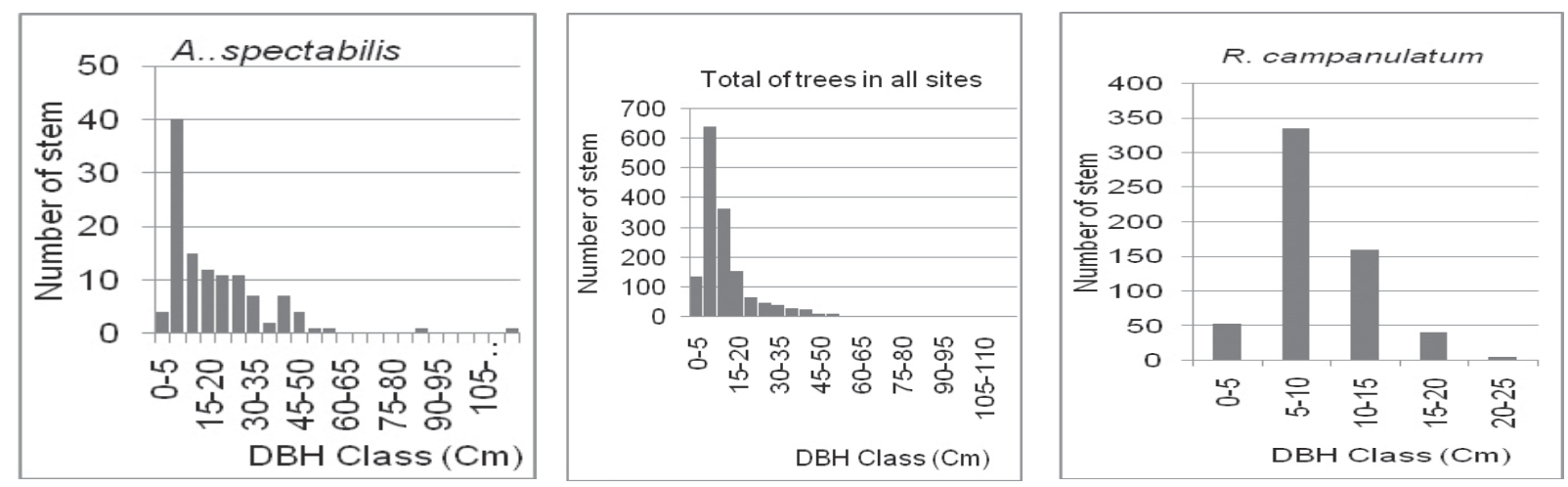

Site I: Churikharka
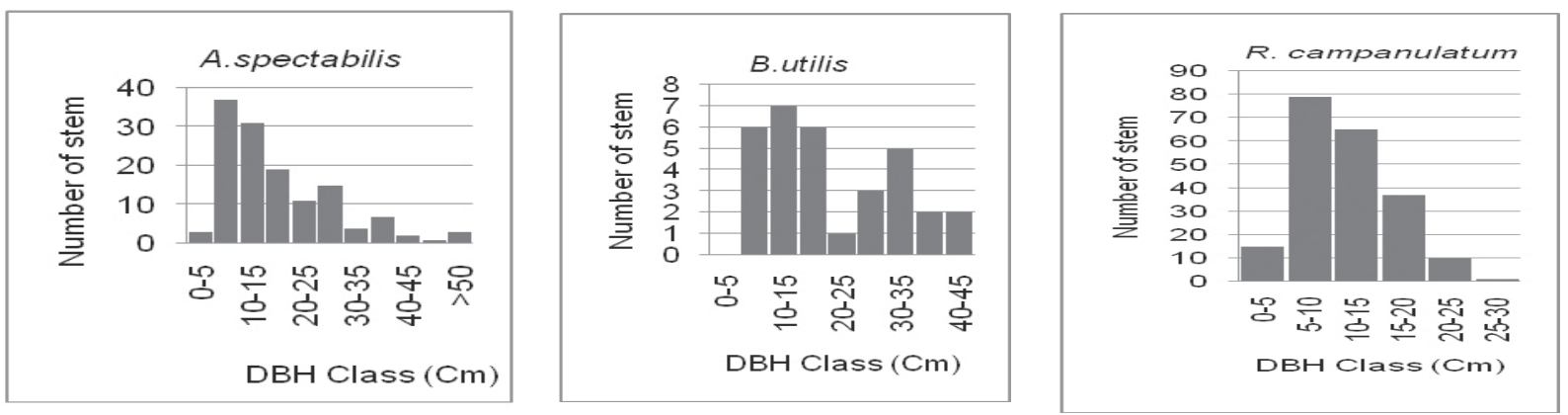

Site II: Between Chaurikharka and Lauribina 
N.P. Gaire et al./Vegetation Dynamics.
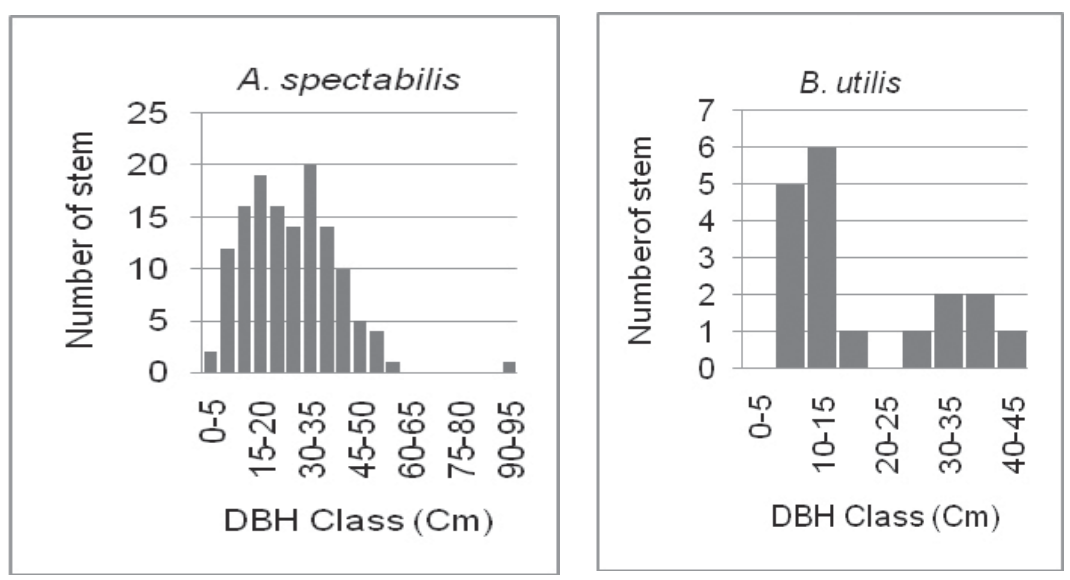

Site III: Lauribina

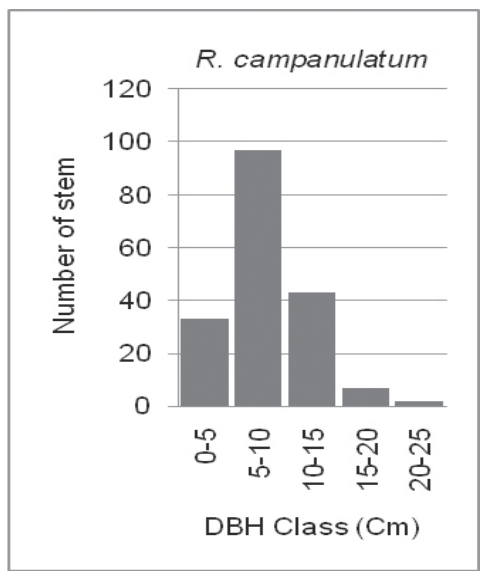

Fig.2. Diameter class distribution of major tree species

Regeneration of canopy dominants is commonly assessed by the distribution of size-classes measured as diameter at breast height (DBH) (West et al. 1981). There were some cut stumps in some plots of Lauribina site, which was reflected in bell shaped distribution of some species. The bimodal distribution might also be due to mixture of two kinds of sample population having two different mean. The diameter distribution of $A$. spectabilis at Lauribina site showed bell-shape curve which is not the indication of sustainable regeneration (Vetaas 2000) and it indicates some anthropogenic pressure or decreasing recruitment. Umans (1993) did not find successful regeneration of Himalay an silver fir (A. spectabilis) in lower subalpine zone of Nepalese Himalaya. In case of unsustainably regenerating forest the diameter distribution diagram shows a bell-shaped structure which means lack of young trees as well as old large tree. Ghimire and Lekhak (2007) found a total absence of higher girth class of $A$. spectabilis trees (above $45 \mathrm{~cm}$ diameter) but present study recorded the diameter up to $115.5 \mathrm{~cm}$ for same species. Similarly, from a study of high altitude forest, Bhuju et al. (2010) observed bell shaped diameter class distribution of $A$. spectabilis and inverse $\mathrm{J}$ shaped distribution of $B$. utilis at treeline (Pangboche) and Just reverse pattern of diameter distribution of these two species at timberline (Debuche). The same study recorded 99cm DBH of $A$. spectabilis and $63 \mathrm{~cm}$ DBH of B. utilis.

\section{Regeneration of tree species}

Table 2 presents densities and frequency of seedling and sapling of tree species. Average per hectare sapling density of tree species was observed to be 1590 with 3045, 595 and 1130 saplings per hectare at sites I, II and III, respectively. Average sapling density of Abies spectabilis was found to be 255 saplings/ha and ranged from 228 in Lauribina to 275 saplings/ha in Chaurikharka site. Saplings of $B$. utilis and S. microphylla were absent in Site I while that of $J$. recurva were absent in site II. Table 2 shows high heterogeneity in sapling densities of tree species. Similarly, average seedling density of tree species was observed to be 831, with 614, 619 and 1261 seedlings/ha for sites I, II and III, respectively. There was a high variation in the seedling densities among different trees as well as among sites. Seedlings of $B$. utilis were absent in Site I while that of $J$. recurva were absent in site II. Average per hectare seedling density of $A$. spectabilis was found to be 350 which ranged from 256 in Lauribina to 479 in between Chaurikharka and Lauribina site. Aspect of the area might be a reason in the variation in the seedling distribution, besides the tree canopy coverage. In some species seedling density of tree species was higher than that of saplings while in some species vice versa was true. In case of $A$. spectabilis the seedling density was higher than that of sapling density in all three sites while other species had no such specific trend. 
Table 2. Status of seedling and sapling in study area

\begin{tabular}{l|l|l|l|l|l|l|l|l|l}
\hline S N & Name of Species & \multicolumn{3}{|c|}{ Sapling Density (saplings/ha) } & \multicolumn{3}{c}{ Seedling Density (seedlings/ha) } \\
\hline \multirow{2}{*}{} & \multirow{2}{*}{ Abies spectabilis } & I & II & III & Average & I & II & III & Average \\
\hline 2 & Betula utilis & 272 & 265 & 228 & 255 & 315 & 479 & 256 & 350 \\
3 & Juniperus recurva & 0 & 6 & 106 & 37 & 0 & 21 & 39 & 20 \\
4 & Rhododendron campanulatum & 198 & 0 & 16 & 71 & 53 & 0 & 91 & 48 \\
5 & Sorbus microphylla & 2575 & 288 & 694 & 1186 & 238 & 27 & 839 & 368 \\
& Total & 0 & 36 & 86 & 41 & 8 & 92 & 36 & 45 \\
\hline
\end{tabular}

Sapling and seedling distribution of tree species was spatially heterogeneous. Spatial heterogeneity in sapling and seedling distribution may be determined by light availability caused by canopy cover, inability of seedling to grow in its upper distribution limit, unavailability of seeds, etc. Total seedling density of all tree species was lower than that of sapling density (Table 4), which is not a normal demographic development. However, there is variation in seedling

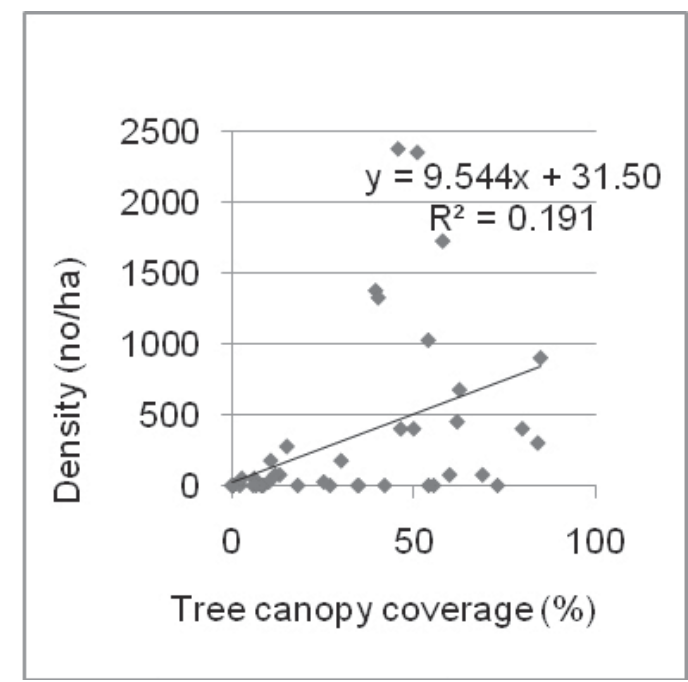

Fig. 3. Relationship between seedling density and tree canopy coverage.

Main focus of the study was in A. spectabilis. Hence, the relationship between seedling density and tree canopy cover as well as between sapling density of $A$. spectabilis and tree canopy cover were analyzed and Figs. 3 and 4 present it. Irrespective of sites, in present study there was positive linear relationship between seedling density and tree canopy cover which was and sapling density among tree species, and average seedling density (330 per ha) of $A$. spectabilis was higher than that of sapling (255 per ha), which is a normal demographic development (West et al. 1981), and is similar to the result of Ghimire and Lekhak (2007). The seedling and sapling ratio of tree species shows higher proportion of sapling than seedling in most species except for $A$. spectabilis for which seedling is higher than sapling indicating recent regeneration.

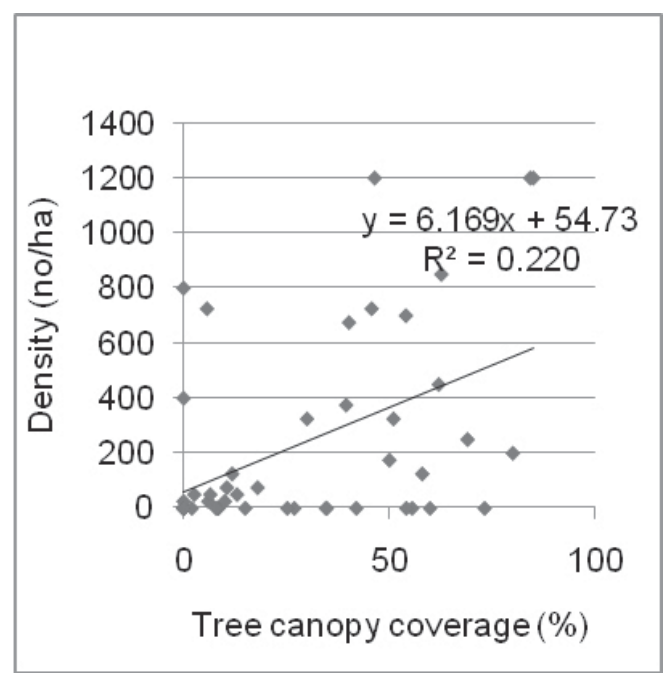

Fig.4. Relationship between sapling density and tree canopy coverage.

statistically significant ( $\mathrm{r}=0.44, \mathrm{P}=0.002$ ) while the linear relationship between sapling and tree canopy was also significant $(\mathrm{r}=0.47, \mathrm{P}=0.001)$. This shows those saplings are more sensitive with tree canopy cover because it might provide shelter against snowfall damage. For seedling the shrub may provide shelter during harsh period. Koirala (2004) found seedling- 
sapling density lower in undisturbed and mature forest which had closed canopy and Shrestha et al. (2007) reported heterogeneous distribution of seedling and sapling linked with canopy cover.

\section{Quantitative study of shrubs}

Table 3 presents various floral composition and structural parameters of shrub species in the sites. Altogether three shrub species were recorded viz. Berberis sp., Rhododendron anthopogan and $R$. lepidotum at site I i.e Churikharka and site III i.e. Lauribina. The site II contained only two species namely: $R$. anthopogan and $R$. lepidotum. The total shrub density ranged from 6,363 in site I to 11,288 per ha in site III while average shrub density for the area was found to be 9,609 per ha. $R$. lepidotum was most frequent shrub species in sites II and III with an average frequency of $75 \%$ and $82 \%$ while Berberis sp. was least frequent shrub species in the study area. Average canopy coverage of shrub species was observed to be $32.6 \%$ of the ground or plots area and which ranged from $14.4 \%$ to $66.1 \%$.

Table 3. Floral composition and structural parameters of shrub species in the study sites

\begin{tabular}{|c|c|c|c|c|c|c|c|c|c|}
\hline & SN & Name of Species & Freq. (\%) & RF (\%) & $\begin{array}{l}\text { Density } \\
\text { (stem/ha) }\end{array}$ & RD (\%) & $\begin{array}{c}\text { Crown Cov. } \\
(\%)\end{array}$ & RC (\%) & IVI \\
\hline \multirow[t]{4}{*}{ Site I } & 1 & Rhododendron anthopogan & 40.6 & 31.8 & 2,100 & 33 & 5.8 & 40.5 & 105 \\
\hline & 2 & Rhododendron lepidotum & 37.5 & 29.3 & 1,475 & 23.2 & 3.7 & 25.5 & 78 \\
\hline & 3 & Berberis sp. & 50 & 39 & 2,788 & 43.8 & 4.9 & 34 & 117 \\
\hline & & Total & 128 & 100 & 6,363 & 100 & 14.4 & 100 & \\
\hline \multirow[t]{3}{*}{ Site II } & 1 & R. anthopogan & 75 & 31.6 & 6775 & 61 & 12.4 & 71.3 & 163.5 \\
\hline & 2 & R. lepidotum & 75 & 31.6 & 4400 & 39 & 5.0 & 28.7 & 99.7 \\
\hline & & Total & 150 & 63.2 & 11175 & 99.9 & 17.4 & 100 & \\
\hline \multirow[t]{4}{*}{ Site III } & 1 & R. anthopogan & 78 & 42 & 7475 & 66.2 & 34.6 & 52.4 & 160.6 \\
\hline & 2 & R. lepidotum & 82 & 46 & 2850 & 25.2 & 28.6 & 43.3 & 114.5 \\
\hline & 3 & Berberis sp. & 22 & 12 & 962.5 & 8.5 & 2.9 & 4.32 & 24.8 \\
\hline & & Total & 184 & 100 & 11288 & 100 & 66.1 & 100 & \\
\hline
\end{tabular}

Note: RF= Relative Frequency, RD= Relative Density, RC= Relative Cover, IVI= Importance Value Index

The studied area was less rich in the shrub species in comparison to other similar study (eg. Kharkwal et al. 2005). Berberis is an unpalatable species. The dominance of this species in some site indicates this site might be under the pressure of cattle grazing. In a study conducted in Khumbu region, Buffa et al. (1998) reported that the overgrazed areas are colonized by unpalatable plants like Cotoneaster and Berberis. In a study from Uttaranchal, Central Himalaya, India, Ram et al. (2004) found total shrubs and herbs richness significantly decreased with increasing tree cover. Although there is no severe direct human disturbance in the study site, other disturbance like grazing, trampling etc were present which may have adverse effect in the forest structure and species richness of this area. Grazing was present in upper plots of site I and III. In upper part of study area where grazing and trampling was seen, the sapling and seedling of conifer was lower than broad leaved Rhododendron. Similarly, Roder et al. (2002) reported that the removal of herbaceous biomass by grazing enhance regeneration of conifer species, reduce damage done by small rodents and grazing diminishes the number and the density of broad leaved species. Human trampling also contributes in species richness and diversity but it also affects the succession through soil compaction (Bhuju \& Ohsawa 1998).

\section{Acknowledgements}

We thank Mr Suman Aryal and Mr Ranjit Pande for their help during field work. We are thankful to the officials of DNPWC and LNP for the permission and providing necessary facilities during the field survey. Resources Himalaya Foundation provided mentorship-grant to the first three authors. 
Nepal Journal of Science and Technology 11 (2010) 107-114

\section{References}

Acharya, K.P., S. Khadka, H.D. Lekhak, R.P Chaudhary and O.R. Vetaas. 2007. Species Composiytion and Regeneration of Coniferous Forest in Manang. In: Local effects of Global Changes in the Himalayas: Manang, Nepal, 2007. (Eds. R.P. Chaudhary, T.S.Aase, O.R.Veetaas, B.P. Subedi). Tribhuvan Univ. Nepal and Univ. of Bergen, Norway. pp131-138.

Becker, A., C. Korner, J.J. Brun, A. Gusian and U. Tappeiner. 2007. Ecological and Land Use Studies Along Elevational Gradients. Mountain Research and Development 27(1):59-65.

Bhuju, D.R. and M. Ohsawa. 1998. Effects of nature trails on ground vegetation and understory colonization of a patchy remnant forest in an urban domain. Biological Conservation 85:123-135.

Bhuju, D.R., M. Carrer, N.P. Gaire, L. Soraruf, R. Riondato, F. Salerno and S.R. Maharjan. 2010. Dendroecological study of high altitude forest at Sagarmatha National Park, Nepal. In: Contemporary research in Sagarmatha (Mt. Everest) region, Nepal (Eds. P.K. Jha \& I.P. Khanal). Nepal Academy of Science and Technology, Lalitpur. pp.119-130.

Buffa, G., C. Ferrari and S. Lovari. 1998. The upper sub alpine vegetation of Sagarmatha National Park (Khumbu Himal area, Nepal) and its relationship with Himalayan Thar, musk deer and domestic yak. In: Top of the world Environmental research: Mount Everest Himalayan Ecosystem (Eds. R. Baudo. G. Tartari \& M. Munawar), Backhuys Publ., Leiden. pp. 167-175.

Camarero, J.J. and E. Gutiérrez. 2004. Pace and pattern of recent treeline dynamics: response of ecotones to climatic variability in the Spanish Pyrenees. Climatic Change 63:181-200.

Ghimire, B. and H.D. Lekhak.2007.Regeneration of Abies spectabilis (D.Don) Mirb. in Subalpine Forest of Upper Manang, North -central Nepal. In: Local effects of Global Changes in the Himalayas: Manang, Nepal, 2007. (Eds.: R.P. Chaudhary, T.S. Aase, O.R. Veetaas, B.P. Subedi). Tribhuvan University, Nepal and University of Bergen, Norway. pp. 139-149.

Grace, J., F. Berninger and L. Nagy. 2002. Impacts of climate change on the tree line. Annals of Botany 90:537-544.

Harcombe, P.A. 1987. Tree life table. Bioscience 37:557-568.
Holtmeier, F.K. and G. Broll. 2005. Sensitivity and response of northern hemisphere altitudinal and polar treelines to environmental change at landscape and local scales. Global Ecology and Biogeography 14:395-410.

Kharkwal, G., P. Mehrotra, Y.S. Rawat and Y.P.S. Pangtey. 2005. Phytodiversity and growth form in relation to altitudinal gradient in the Central Himalayan (Kumaun) region of India. Current Science 89(5): 873878.

Koirala, M. 2004. Vegetation composition and diversity of Piluwa micro-watershed in Tinjure-Milke region, east Nepal. Himalayan journal of Sciences 2(3):29-32.

Kullman, L. 1998. Tree-limits and montane forests in the Swedish Scandes: sensitive biomonitors of climate change and variability. Ambio. 27:312-321.

Kullman, L. 2002. Rapid recent range-margin rise of tree and shrub species in the Swedish Scandes. Journal of Ecology 90:68-77.

Kullman, L. 2007. Tree line population monitoring of Pinus sylvestrisin the Swedish Scandes, 1973-2005: Implications for tree line theory and climate change ecology. Journal of Ecology 95:41-52.

Ohsawa, M. 1984. Differentiation of vegetation zones and species strategies in the sub- alpine region of Mount Fuji. Vegetatio 57:15-52.

Ram, J., A. Kumar and J. Bhatt 2004. Plant diversity in six forest types of Uttaranchal, Central Himalaya, India. Current Science 86 (7):975-978.

Roder, W., G. Gratzer and K.Wangdi. 2002. Cattle grazing in the conifer forests of Bhutan. Mountain Research and Development 22(4):368-374.

Shrestha B.B., B. Ghimire, H.D. Lekhak and P.K. Jha. 2007. Regeneration of Treeline Birch (Betula utilis D.Don) Forest in trans-Himalayan Dry Valley in Central Nepal. Mountain Research and Development 27(3):250-258.

Umans, L.1993. The unsustainable flow of Himalayan fir timber. Mountain Research and Development 13(1):73-88.

Vetaas, O.R. 2000. The effect of environmental factors on regeneration of Quercus semecarpifolia Sm. in central Himalaya, Nepal. Plant Ecology, 146:137-44.

Wang, T., Q-B. Zhang and K. Ma. 2006. Treeline dynamics in relation to climatic variability in the central Tianshan Mountains, northwestern China. Global Ecology and Biogeography 15:406-415.

West, D.C., H.H. Shugart and J.W. Ranney. 1981. Population structure over a large area. Forest Science 27:701-710. 